(UDC: $621.822 .5: 532.54)$

\title{
Magnetic Fluid Lubrication of an Infinitely Long Slider Bearing with Rough Surfaces
}

\author{
M. P. Patel ${ }^{*}$, Dr. H. C. Patel ${ }^{2}$, Dr. G. M. Deheri ${ }^{3}$ \\ ${ }^{1}$ General Department, K. D. Polytechnic, Patan, Gujarat, India. \\ mehul090487@gmail.com \\ ${ }^{2}$ Gujarat University, Ahmedabad, Gujarat, India. \\ dr.prof.hcpatel@gmail.com \\ ${ }^{3}$ Department of Mathematics, V.V. Nagar, Anand, Gujarat, India. \\ gm.deheri@rediff.com \\ * Corresponding author
}

\begin{abstract}
This article deals with the performance characteristics of an infinite slider bearing with rough surfaces in the presence of a magnetic fluid as the lubricant. The magnetic fluid flow model of Neuringer Rosenwicg has been used here. The stochastic model of Christensen and Tonder has been adopted to evaluate the effect of surface roughness. The related stochastically averaged Reynolds equation is solved to obtain the pressure distribution leading to the calculation of load carrying capacity. The results presented in graphical forms suggest that the adverse effect of transverse roughness can be minimized by choosing suitable magnetic strength. It is observed that the negativity-skewed roughness plays an important role in improving the bearing performance.
\end{abstract}

Keywords: Slider bearing, magneticfluid, roughness, loads carrying capacity.

\section{Introduction}

Fluids with strong magnetic properties have attracted considerable attention during the last decade. The use of the magnetic fluid as a lubricant for the bearing system in technical applications in the domain of nano scale science and technology has made significant progress. Magnetic fluid consists of colloidal magnetic nano particles dispersed with the aid of surfactants in a carrier liquid. In reality, magnetic fluid is a hybrid of soft material and the nano particles. The average diameter of the dispersed particles ranges from 3 to $10 \mathrm{~nm}$. The ferrofluids contain enormous magnetic nanoparticles and, therefore, can be influenced by either parallel or perpendicular magnetic field. The use of magnetic fluid has resulted in the development of many energy devices and instruments. Computer disks drives, semiconductors and high precision speakers are commercially available and based on magnetic fluid effects. The most important property of a magnetic fluid is that it can be retained at a desired location under the magnetic field. When a magnetic field is applied, each and every particle experiences a body force causing it to flow. 
In most of the studies conventional lubricants were used. The use of magnetic fluid as a lubricant modifying the performance of the bearings has been well established. The application of magnetic fluid as a lubricant was investigated by many authors (Agrawal (1986), Bhat and Deheri (1995), Odenbach (2004), Nada and Osman (2007), Urreta et al. (2009), Huang et al. (2011)). In all these studies it has been established that the performance of bearing system could be improved by using a magnetic fluid as the lubricant.

In the field of engineering and technology, slider bearings are widely used because of their stability, durability and high load carrying capacity. The contribution of surface roughness and properties of lubricant film on the load carrying capacity and friction is an important aspect in the analysis of slider bearings. The researchers have carried out the study of performance characteristics of slider bearings with different lubricants from time to time. Surface roughness evaluation is very important for many fundamental problems such as friction, load carrying capacity, contact deformation, heat and electric current conditions. For this reason, surface has been the subject of experimental and theoretical investigations for many decades. In literature, many investigations, such as Tzeng and Saibel (1967), Christensen and Tonder (1969a, 1969b, 1970), Gupta and Deheri (1996), accounting for surface roughness effect, have been proposed in order to seek a more realistic representation of bearing surfaces. Patel and Deheri (2009) analyzed the characteristics of lubrication at nano scale on the performance of transversely rough slider bearing. Sinha and Adamu (2009) studied the thermal and roughness effects on different characteristics of an infinite tilted pad slider bearing. In this paper roughness was assumed to be stochastic, and the method was developed using the models of Christensen and Tonder (1969a, 1969b, 1970). Lin et al. (2004) analyzed the squeeze-film performance between curved annular plates with an electrically conducting fluid in the presence of a transverse magnetic field. Deheri et al. (2005) discussed the effect of transverse roughness on the behavior of slider bearings with squeeze film formed by a magnetic fluid. Lin et al. (2006) observed the effects of fluid inertia on the squeeze film behavior between two parallel annular disks with an electrically conducting fluid in the presence of a transverse magnetic field. Shimpi and Deheri (2012) dealt with the performance of a magnetic fluid based rough short bearing incorporating deformation effect. Deheri et al. (2013) investigated the performance characteristics of a hydrodynamic long journal bearing taking recourse to a magnetic fluid lubricant. Patel and Deheri (2014) analyzed the combined effect of roughness and slip velocity on the performance of a ferrofluid based rough porous hyperbolic slider bearing.

Here it has been thought proper to discuss the performance characteristics of an infinitely long slider bearing with rough surfaces under the presence of a magnetic fluid.

\section{Analysis}

The configuration of the bearing, which is infinite in the $\mathrm{Z}$ direction, is presented in Fig. 1. It consists of two rough surfaces separated by a lubricant film. The lower surface is moving with the uniform velocity $U$ in the $\mathrm{X}$ direction, while the upper surface is stationary. The length of the bearing is $L$ while $h_{0}$ and $h_{1}$ being the minimum and maximum film thickness. The bearing surfaces are assumed to be transversely rough. 


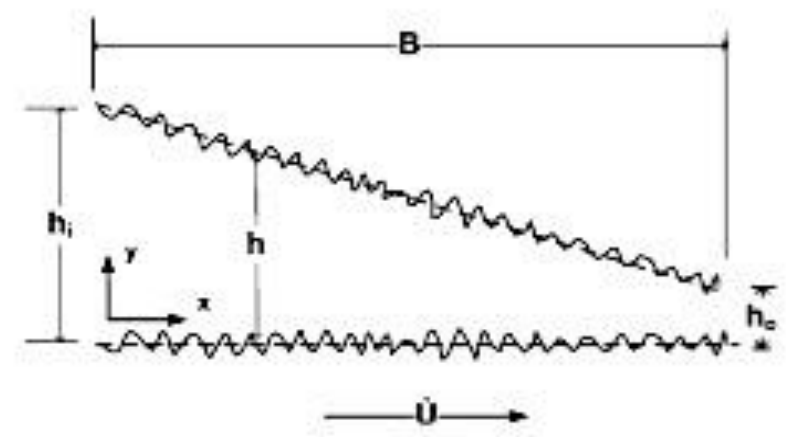

Fig. 1. Following the discussions of Christensen and Tonder the stochastic film thickness is taken as:

$$
H(x, z, \varepsilon)=h(x)+\delta(x, z, \varepsilon)
$$

where $h$ is the nominal (smooth) part which measures the large scale part of the film geometry including any long wave length disturbances, and $\delta$ is a randomly varying quantity with zero mean, which arises due to the surface roughness measured from the nominal level. In this theory, the film thickness is assumed to be of such a form that the application of the Reynolds equation remains valid. This requirement is basic and quite unconnected with the idea of viewing film thickness as a stochastic process. Christensen and Tonder (1969a) and Christensen (1969) have made the following assumptions:

1. The magnitude of the pressure ripples associated with the surface roughness is small compared to the general pressure level in the bearing, and consequently, the variance of the pressure gradient in the roughness direction is negligible.

2. In the direction perpendicular to the roughness direction, the variance of unit flow is negligible.

3. The magnitudes of temperature and velocities associated with roughness are small compared to the corresponding general magnitudes in the bearing.

The details discussion regarding this aspect can be found in the investigation of Christensen and Tonder (1969a) and Christensen (1969).

Following the averaging method of Christensen and Tonder the roughness turns out to be:

$$
h^{3}+3 h \sigma^{2}+3 h^{2} \sigma+3 h \alpha^{2}+3 \sigma^{2} \alpha+\alpha^{3}+\varepsilon
$$

Following the investigations of Agrawal (1986) and Bhat (2003) the magnitude $\mathrm{H}$ of the magnetic field $\bar{H}$ is taken as:

$$
H^{2}=K x(l-x)
$$

$\mathrm{K}$ being a quantity chosen to suit the dimensions so as to manufacture a magnetic field of required strength.

In view of usual assumptions of hydrodynamic lubrications, the lubricant film is taken to be isoviscous, incompressible, and the flow is laminar. Following the method of Sinha (2009), Agrawal (1986) and Deheri (2014) and adopting the stochastic averaging by the method of Christensen and Tonder, the Reynolds equation governing the pressure distribution is obtained as: 


$$
\frac{\partial}{\partial x}\left(\frac{1}{\mu} E\left(H^{3}\right) \frac{d}{d x}\left(p-\frac{\mu_{o} \bar{\mu} H^{2}}{2}\right)\right)=6 U \frac{\partial}{\partial x}(E(H))
$$

where

$$
\begin{gathered}
E\left(H^{3}\right)=h^{3}+3 h \sigma^{2}+3 h^{2} \sigma+3 h \alpha^{2}+3 \sigma^{2} \alpha+\alpha^{3}+\varepsilon \\
E(H)=h .
\end{gathered}
$$

The associated boundary conditions are:

$$
p=0 \text { at } x=0 \text { and } x=B
$$

Introduction of dimensionless quantities

$$
X=\frac{x}{B}, H=\frac{h}{h_{0}}, \sigma^{*}=\frac{\sigma}{h_{0}}, \alpha^{*}=\frac{\alpha}{h_{0}}, \varepsilon^{*}=\frac{\varepsilon}{h_{0}}, G(H)=\frac{E\left(H^{3}\right)}{h_{0}{ }^{3}}, P=\frac{p h_{0}{ }^{2}}{6 U \mu L}, \mu^{*}=\frac{\mu_{0} \bar{\mu} K B h_{0}{ }^{2}}{6 \mu U}
$$

leads to the dimensionless Reynolds equation:

$$
\frac{\partial}{\partial X}\left(G(H) \frac{d}{d X}\left(P-\frac{1}{2} \mu^{*} X(1-X)\right)\right)=\frac{\partial H}{\partial X}
$$

Integrating both sides one finds that

$$
\frac{d}{d X}\left(P-\frac{1}{2} \mu^{*} X(1-X)\right)=\frac{H-H_{m}}{G(H)}
$$

where subscript $\mathrm{m}$ refers to the condition at point where

$$
\frac{d P}{d X}=0 \text {. }
$$

The associated boundary conditions are

$$
P=0 \text { at } X=0 \text { and } X=1
$$

Then, the expression for nondimensional pressure distribution is found to be:

$$
P(X)=\frac{1}{2} \mu^{*} X(1-X)+\int_{0}^{X} \frac{H-H_{m}}{G(H)} d X
$$

where

$$
H_{m}=\frac{\int_{0}^{1} \frac{1}{G(H)} d X}{\int_{0}^{1} \frac{H}{G(H)} d X}
$$

Lastly, the dimensionless load-carrying capacity is obtained from the relation:

$$
W=\int_{0}^{1} P(X) d X
$$

\section{Results and discussions}

It is clearly seen that the equation:

$$
P(X)=\frac{1}{2} \mu^{*} X(1-X)+\int_{0}^{X} \frac{H-H_{m}}{G(H)} d X
$$

determines the pressure distribution while the load carrying capacity is obtained from: 


$$
W=\int_{0}^{1} P(X) d X
$$

Both these equations depend on various parameters such as $\mu^{*}, \sigma^{*}, \alpha^{*}, \varepsilon^{*}$. The first parameter describes the effect of magnetization while the remaining three parameters decide effect of roughness.

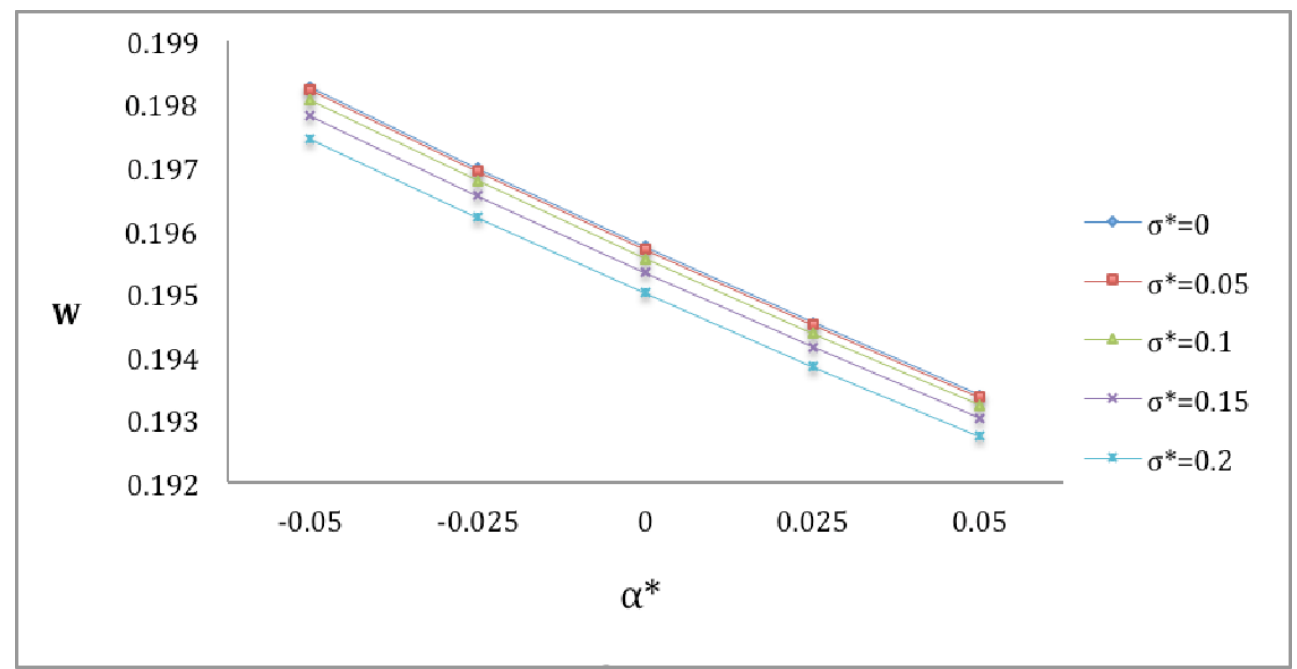

Fig. 2. indicates that load carrying capacity decreases with increased standard deviation, which does not happen in case of longitudinal roughness. Besides, variance $(+\mathrm{Ve})$ decreases the load

carrying capacity while the load carrying capacity gets increased due to variance $(-\mathrm{Ve})$.

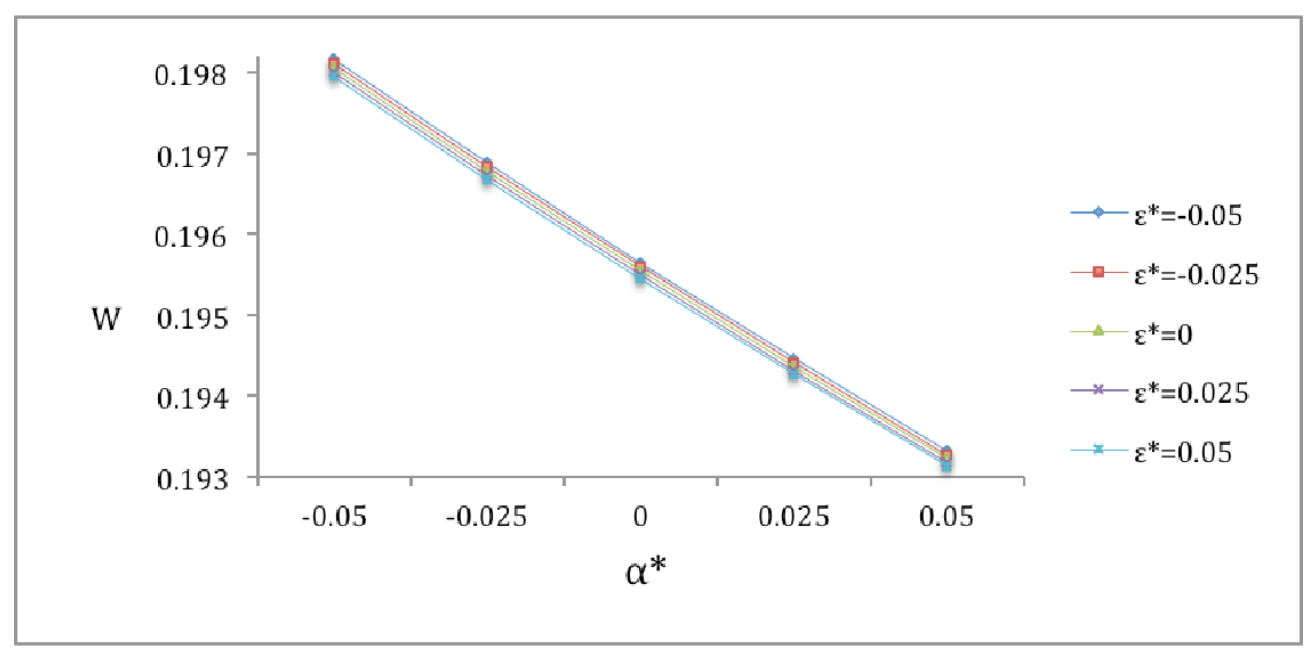

Fig. 3. The fact that the trends of load carrying capacity with respect to skewedness are similar to that of variance is reflected in Fig.3. Of course, the effect of skewedness on the load carrying capacity with respect to variance is nominal. 


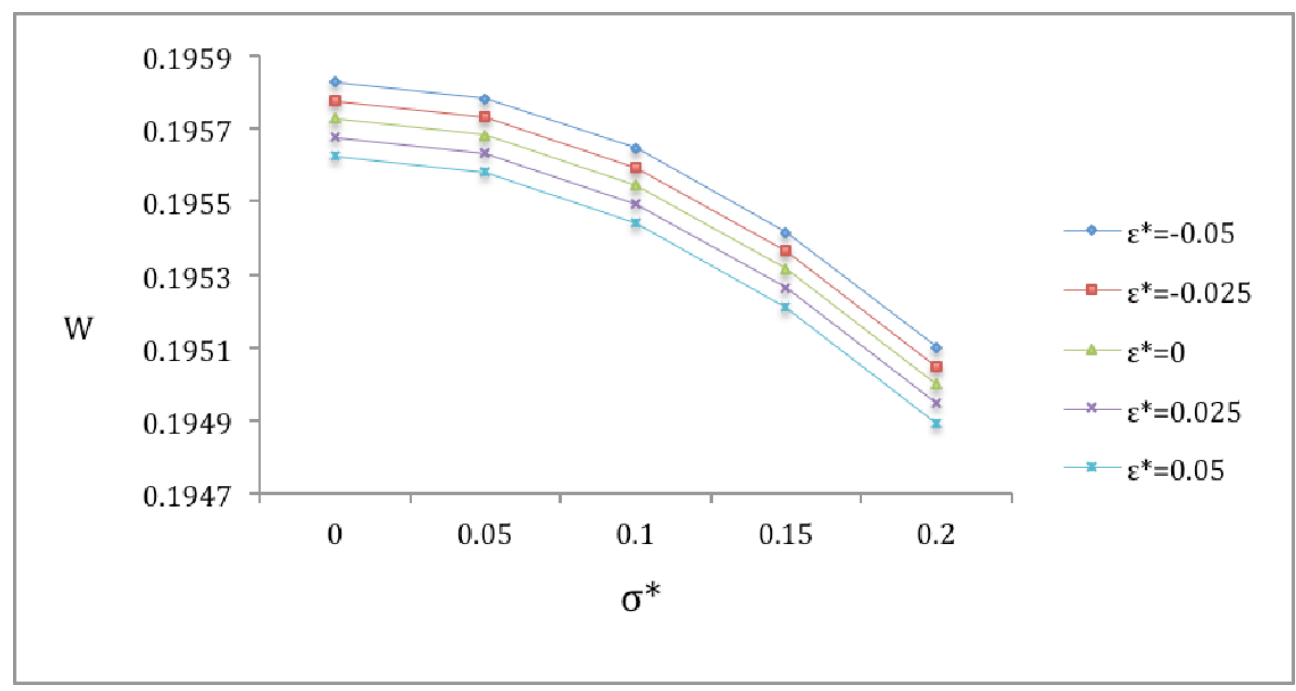

Fig. 4. displays that the positively skewed roughness compounds the negative effect of standard deviation.

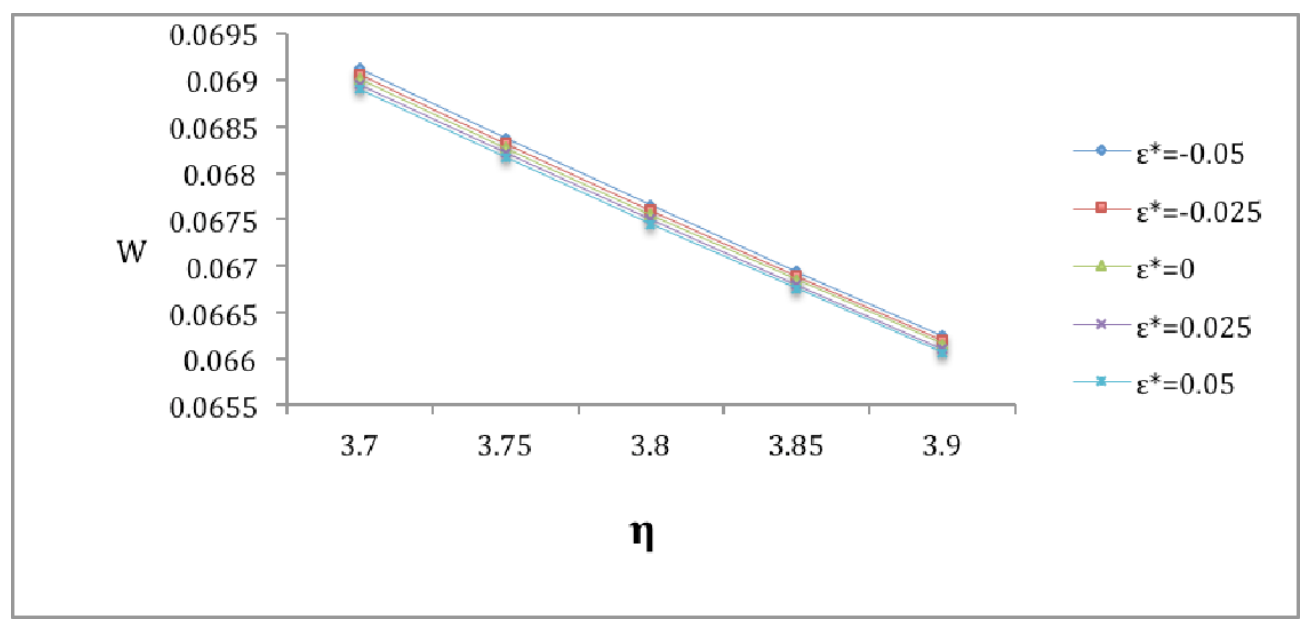

Fig. 5. suggests that the effect of skewness on the variation of load carrying capacity with respect to the film thickness ratio is almost nominal. It is established that the positive effect of variance (-ve) gets enhanced by the negatively skewed roughness, which may go a long way in improving the performance of the bearing system. 


\begin{tabular}{|c|c|c|c|c|c|}
\hline$\sigma^{*}$ & $\mu^{*}=0.1$ & $\mu^{*}=0.2$ & $\mu^{*}=0.3$ & $\mu^{*}=0.4$ & $\mu^{*}=0.5$ \\
\hline 0 & 0.051062318 & 0.059395651 & 0.067728985 & 0.076062318 & 0.084395651 \\
\hline 0.05 & 0.05101616 & 0.059349493 & 0.067682827 & 0.07601616 & 0.084349493 \\
\hline 0.1 & 0.050878055 & 0.059211388 & 0.067544722 & 0.07601616 & 0.084211388 \\
\hline 0.15 & 0.050649185 & 0.058982518 & 0.067315852 & 0.075649185 & 0.083982518 \\
\hline 0.2 & 0.050331731 & 0.058665064 & 0.066998397 & 0.075331731 & 0.083665064 \\
\hline \multicolumn{6}{|l|}{$\varepsilon^{*}$} \\
\hline-0.05 & 0.050977085 & 0.059310419 & 0.067643752 & 0.075977085 & 0.084310419 \\
\hline-0.025 & 0.050928081 & 0.059261414 & 0.067594748 & 0.075928081 & 0.084261414 \\
\hline 0 & 0.050878055 & 0.059211388 & 0.067544722 & 0.075878055 & 0.084211388 \\
\hline 0.025 & 0.050827103 & 0.059160436 & 0.067493769 & 0.075827103 & 0.084160436 \\
\hline-0.05 & 0.050775309 & 0.059108643 & 0.067441976 & 0.075775309 & 0.084108643 \\
\hline \multicolumn{6}{|l|}{$\alpha^{*}$} \\
\hline-0.05 & 0.096061181 & 0.147061181 & 0.198061181 & 0.249061181 & 0.300061181 \\
\hline-0.025 & 0.09477764 & 0.14577764 & 0.19677764 & 0.24777764 & 0.29877764 \\
\hline 0 & 0.093544722 & 0.144544722 & 0.195544722 & 0.246544722 & 0.297544722 \\
\hline 0.025 & 0.092359836 & 0.143359836 & 0.194359836 & 0.245359836 & 0.29635986 \\
\hline-0.05 & 0.09122056 & 0.14222056 & 0.19322056 & 0.24422056 & 0.29522056 \\
\hline
\end{tabular}

Table 1. Variation in Load carrying capacity with respect to $\sigma^{*}, \varepsilon^{*}, \alpha^{*}$

From Table 1 it is concluded that the load carrying capacity sharply rises due to magnetization, which may be due to the fact that the viscosity of the lubricant increases owing to the magnetization. It is interesting to note that for this type of bearing, system magnetization does not allow the load carrying capacity to be affected much due to roughness parameters.

\title{
4. Conclusion
}

Although the effect of negatively skewed roughness remains positive while designing the bearing system, the roughness aspects must be evaluated. For this type of bearing system the bearing may turn in an enhanced performance irrespective of the fact that the machine has run for a long time.

Извод

\section{Лубрикација магнетног флуида код бесконачног клизног лежаја храпаве површине}

\author{
M. P. Patel ${ }^{*}$, Dr. H. C. Patel ${ }^{2}$, Dr. G. M. Deheri ${ }^{3}$
}

${ }^{1}$ General Department, K. D. Polytechnic, Patan, Gujarat, India.

mehu1090487@gmail.com

${ }^{2}$ Gujarat University, Ahmedabad, Gujarat, India.

dr.prof.hcpatel@gmail.com

${ }^{3}$ Department of Mathematics, V.V. Nagar, Anand, Gujarat, India.

gm.deheri@rediff.com

* Corresponding author 


\section{Резиме}

У овом раду се анализирају карактеристике перформанси бесконачног клизног лежаја храпаве површине у присуству магнетног флуида као лубриканта. Коришћен је Neuringer Rosenwicg модел протока магнетног флуида. За процену утицаја храпавости површине примењен је Christensen и Tonder-ов стохастички модел. Одговарајућа стохастички усредњена једначина Рејнолдсовог типа је решена да би се добила дистрибуција притиска и након тога израчунао капацитет носивости. Резултати приказани графички показују да се нежељени утицај трансферзалне храпавости може свести на минимум уколико се одабере одговарајућа снага магнета. Запажа се да негативно закошена храпава површина има важну улогу у побољшању перформанси лежаја.

Кључне речи: клизни лежај, магнетни флуид, храпавост, капацитет носивости.

\section{References}

Agrawal VK (1986). Magnetic fluid based porous inclined slider bearing, WEAR, 107, 133139.

Bhat MV and Deheri GM (1995). Porous slider bearing with squeeze film formed by a magnetic fluid, Pure and Applied Mathematika Sciences, 39 (1-2), 39-43.

Christensen H (1969). Stochastic models of hydrodynamic lubrication of rough surfaces. In: Proc. Inst. Mech. Eng. 184, 1013-1022.

Christensen H. and Tonder KC (1969a). Tribology of rough surfaces: stochastic models of hydrodynamic lubrication, SINTEF, Report No.10/69-18.

Christensen H. and Tonder KC (1969b). Tribology of rough surfaces: parametric study and comparison of lubrication models, SINTEF, Report No.22/69-18.

Christensen, H.(1969): Stochastic models of hydrodynamic lubrication of rough surfaces. In: Proc. Inst. Mech. Eng. 184, 1013-1022.

Deheri GM, Andharia PI,Patel RM(2005).Transversely rough slider bearings with squeeze film formed by a magnetic fluid, Int. J. of Applied Mechanics and Engineering, 10, 1, 53- 76.

Gupta JL and Deheri GM (1996). Effect of Roughness on the Behavior of Squeeze Film in a Spherical Bearing, Tribology Transactions, 39, 99-102.

Himanshu CP, Deheri GM (2009). Characteristics of lubrication at nano scale on the performance of transversely rough slider bearing MECHANIKA. 6(80).

Huang W, Shen C, Liao S and Wang X (2011). Study on the ferrofluid lubrication with an external magnetic field, Tribology Lett., 41, 145-151.

Lin JR, Lu RF, Liao WH (2004). Analysis of magneto-hydrodynamic squeeze film charecteristics between curved annular plates, Industrial Lubrication and Tribology, 56, 5, 300-305.

Lu, RF, Chien, RDLin JR(2006). Effects of fluid inertia in magneto-hydrodynamic annular squeeze films, Tribology International, 39, 3, 221-226.

Nada G S and Osman TA (2004). Static performance of finite hydrodynamic journal bearings lubricated by magnetic fluids with couple stresses, Tribology Letters, 27, 261-268

Odenbach S. (2004). Recent progress in magnetic fluid research, Journal of physics condensed matter, 16. R1135-R1150.

Patel NS, Vakharia DP, Deheri GM, Patel HC (2013).The Performance Analysis of a Magnetic Fluid-Based Hydrodynamic Long Journal Bearing Proceedings of ICATES, 117-126, ISBN: 978-81-322-1655-1 (Print).

Patel SJ, Deheri GM, Patel JR(2014). Ferrofluid Lubrication of a Rough Porous Hyperbolic Slider Bearing with Slip Velocity. Tribology in Industry. 36, 3, 259-268. 
Prawal S, Getachew A (2009).THD analysis for slider bearing with roughness: special reference to load generation in parallel sliders. Acta Mechanica. 207, 1-2, 11-27.

Shimpi ME, Deheri GM (2012). Effect of deformation in magnetic fluid based transversely rough short bearing. Tribology-Materials, Surfaces \& Interfaces., 6, 1,20-24.

Tzeng ST and Saibel E (1967). Surface roughness effect on slider bearing lubrication, Trans. ASLE, 10, 334-340.

Urreta H, Leicht Z, Sanchez A, Agirre A, Kuzhir P and Magnac G. Hydrodynamic bearing lubricated with magnetic fluids, Journal of Physics: Conference series, 149(1), Article ID 012113. 